\title{
Analysis of Non-adoption and Discontinuance of Improved Oil Palm Fruit Processing Technology in Kogi State, North Central Nigeria
}

\author{
Adah, Obe Christopher ${ }^{1} \quad$ Akoh, Thankgod Ameh ${ }^{2} \quad$ Oluyomi, Moses Sunday ${ }^{2}$ \\ 1.Department of Agricultural Economics \& Extension, Kogi State University, Anyigba \\ 2.Department of Agricultural Education, Kogi State College of Education, Ankpa \\ In Affiliation with: \\ Abubakar Tafawa Balewa University, Bauchi,Nigeria
}

\begin{abstract}
The study analyzed non-adoption and discontinuance of improved oil palm fruit processing technology in Kogi State, North central Nigeria. Using purposive multi-stage sampling technique, a sample of 240 oil palm fruit processors was taken from three agricultural zones of the study area to represent the population. Structured questionnaire was used to collect the data for the study. Organization and description of data were realized by the use of frequency distribution table, percentage, ranking and mean. The findings indicated that significant proportion $(60.4 \%)$ of the respondents were female with a mean age of 43 years and an average household size of 8 persons. Seventy-three percent of the respondents were married, while $82.5 \%$ had formal education. The oil palm processors had 16 years of processing experience; $62.5 \%$ of the respondents had less than 5 extension contacts annually. Majority (63.8\%) and $2.5 \%$ of the respondents did not adopt and discontinue use of the improved oil palm fruit processing technology respectively. Out of 153 respondents that did not adopt the technology, $68.6 \%$ and $67.3 \%$ gave their non-adoption reasons as high cost of machine and low level of extension visits respectively. Also, $100.0 \%$ of the respondents that discontinued the use of the technology gave high cost of machine as their reason, while $92.8 \%$ and $78.6 \%$ felt they had low level of extension visits and poor quality of oil produced using the machine respectively. Based on the findings of the study, it was recommended that the improved oil palm fruit processing machine should be made affordable to processors by ways of both governmental and manufacturers subsidy policies to encourage prospective adoption of the technologies among others.
\end{abstract}

Keywords: Non-adoption, Discontinuance, Improved, Oil Palm Fruit, Processing, Technology.

DOI: $10.7176 / \mathrm{JBAH} / 9-18-01$

Publication date:September $30^{\text {th }} 2019$

\subsection{Introduction}

Oil palm fruit processing into palm oil is a major source of income generation and employment to a large proportion of the resource poor rural population in Nigeria, especially in the southern and part of the middle belt regions of the country. Processing of the palm fruits into palm oil according to Omereji (2005) is one of the most difficult activities in traditional palm oil processing in Nigeria. It involves series of activities which include harvesting of the palm fruit bunches, transportation (including loading and off-loading), stripping, sterilization and oil extraction.

At present, the processing of this crop which used to be wholly and traditionally manual is going partially or fully mechanized as a result of drudgery and inability of the manual processing to satisfy growing demands for palm oil, a popularly consumed oil palm product in Nigeria society (Owolarafe, Taiwo and Oke, 2008). So its supply to meet up with the increasing demands can be promoted by the method of processing.

Adah and Obinne (2015) asserted that it is a common knowledge that use of machines (improved processing method or technology) enhances production. Hence, the issue of adoption of the improved processing method becomes very significant, especially as the adoption level of any particular technology is dependent on the nature of such technology. Supporting this assertion, Rogers and Shoemaker (1971) conceptualized that agricultural innovations vary tremendously in their inherent characteristics, which to a large extent influence the decision of the farmers to participate or not. This is because farmers are more inclined to acceptance of recommended practices if they are profitable, compatible with the existing farming system, divisible, simple to use, have relevance for their labour use as well as community values. In the same vein, Onoh and Peter - Onoh (2012) reported in a study that while local oil processing recorded high score value of $91.23 \%$, the improved technology adoption recorded very low score value of $3.75 \%$. The poor adoption rate recorded for improved processing technology could be attributed to costs and complexity associated with machines.

Non - adoption and /or discontinuance could be looked at as the last stage in the adoption process. Discontinuance is the giving up of a new practice after initial acceptance (Akubuilo, 2008). Discontinuance of production/processing technologies could be as a result of several factors. Hence, Khan et al. (1991) observed that the new technology may not be adopted by the farmers if recommended inputs are not available in the desired 
quantities, required qualities and at proper time and place and farmers do not have the financial resources to purchase these inputs because it is only few of the farmers that can save enough from their meagre earnings to enable them take full advantage of the ever increasing range of improved technologies and tools which science has made available for profitable farming. The objectives of this study therefore were to: describe the socio-economic characteristics of oil palm processors in the study area; and identify reasons for non-adoption and discontinuance of the improved oil palm fruit processing technology in the study area.

\subsection{Methodology}

The study took place in Kogi State, North central Nigeria. Oil palm production and processing are major activities in the study area. A multi-stage sampling technique was used to select 240 oil palm fruit processors for the study. The stratification was based on the existing four agricultural development programme administrative zones in Kogi State which include Zones A (Aiyetoro-Gbede); B (Anyigba); C (koton-karfe) and D (Alloma). The zones have 6 extension blocks (EBs) each with 8 cells per each block. Based on the concentration of oil palm processing activities, 3 zones: A,B and D were purposively selected with 48 oil palm fruit processors for one zone(A) and 96 respondents for each of the two remaining zones(B and D). Data were collected using structured questionnaire.

Data obtained were analyzed using descriptive statistics such as frequency distribution tables, percentages, ranking and means.

\subsection{Results and Discussions}

\subsection{Socio-economic Characteristics of Oil Palm Processors}

The socio-economic characteristics of oil palm processors in the study area are presented in Table 1 . In the study area, oil palm fruit processing enterprise is undertaken irrespective of sex. The dominance of female oil palm processors could be attributed to the nature of work done in oil palm processing such as cooking palm fruits, manual fibre separation, washing of equipment and containers, cooking of crude oil for clarification, packing of oil fibre and nuts, which is socially regarded as female responsibility in our society (Adah and Obinne, 2015). This finding is in line with that of Nsoanya and Nenna (2011); and Korie et al. (2013).

Table 1 further reveals that the oil palm fruit processing enterprise is in the hands of the matured and economically viable population whose ages range from 20 to 60 years. According to Adah and Obinne (2015) the youthful nature of the age distribution is also an added advantage in terms of longevity of the trade and the predisposition to innovation adoption. This finding is in agreement with that of Onoh and Peter-Onoh (2012) that majority of the oil palm farmers and processors fall within the agile and active age range of 40-60 years.

The greater proportion of the oil palm fruit processors in the study area had household sizes ranging from 5 to $10(72.92 \%)$, with an average household size of 8 which is slightly higher than the national average of 7(Adah and Obinne, 2015). This finding is in consonance with that of Oluyomi et al. (2016) who reported that yam farmers who utilized yam minisett technology in Benue State had household sizes ranging from 5-10 (56.6\%). This is also similar to the findings of Korie et al. (2013) suggesting a high level of labour availability (Adah and Obinne, 2015).

Data from Table 1 further indicates that $73.3 \%$ of the oil palm fruit processors were married. According to Adah, Chia and Shaibu (2016) marital status determines an individual's decision to demonstrate a mark of social responsibility and also indicate a readily available source of labour input. Still stressing on the significance of marital status of oil palm fruit processors, Adegeye and Dittoh (1985) in Adah et al. (2016) declared that smallscale farmers; and by extension, oil palm processors could only be successful if they were married especially when they had to rely on family labour.

Also, $82.8 \%$ of the oil palm processors were literate at various levels of education. The mean educational level was 8.5 years. According to Adah et al. (2016), education increases farmers' decision to accept agricultural innovation such as the agricultural insurance scheme; and by extension improved oil palm fruit processing technology. This finding is in consonance with the earlier finding of Obinne (1991) in Adah and Obinne (2015) that education is a factor in the adoption of higher yielding modern technologies. Also, Agwu (2006) attested to the finding that high literacy level has a positive effect on adoption of innovative oil palm practices. Hornik (1999) and Motuma et al. (2010) have underscored the importance of education in agricultural production. Conversely, the low percentage (17.5\%) recorded for lack of formal education is an advantage for innovation adoption and transfer (Nsoanya and Nenna, 2011). Similarly, Olagunju (2008) reported that education plays an important role in palm oil processing operations since it will facilitate the adoption of innovations that will improve palm oil processing.

Table 1 also relays that the average year of experience in oil palm fruit processing was 16 years. This suggests that the oil palm fruit processors in the study area were largely experienced. Adah and Obinne (2015) reported that experience comes with time and has proven to be of great advantage especially as the level of mastery increases with it. Adah et al. (2016) also reported that farming experience could also increase the adoption of agricultural innovation like the agricultural insurance scheme; and by extension improved oil palm fruit processing technology. Increased years of oil palm processing expose processors to various methods of processing and their likelihood to 
accept the improved processing technology. This finding agrees with Idrisa et al. (2012) who reported that experience depicts a good signal for adoption since it helps to convince the farmer of the importance of innovation. Agbamu (2006) in Adah et al. (2016) believes that experience impacts positively on innovation adoption.

Data in Table 1 also indicate that $62.5 \%$ of the oil palm fruit processors in the study area had less than 5 contacts with extension agents in the course of the year covered by the study. Zegeye (1990); Onemolease and Alakpa (2009) in Adah and Obinne (2015) reported that contact with extension workers is known to facilitate farmers' adoption of improved technologies, including improved oil palm fruit processing technology. Such contacts according to Voh (1982) in Adah and Obinne (2015) by exposing farmers to availability of information can be expected to stimulate adoption.

Table 1: Socio-economic Characteristics of Oil Palm Fruit Processors

\begin{tabular}{|c|c|c|c|}
\hline Variable & Frequency & Percentage (\%) & Mean \\
\hline \multicolumn{4}{|l|}{ Sex } \\
\hline Male & 95 & 39.6 & \\
\hline Female & 145 & 60.4 & \\
\hline \multicolumn{4}{|c|}{ Age in Years } \\
\hline $20-30$ & 39 & 16.3 & \multirow{5}{*}{$42.8(\mathrm{SD}=11.0)$} \\
\hline $31-40$ & 38 & 15.8 & \\
\hline $41-50$ & 87 & 36.3 & \\
\hline $51-60$ & 60 & 25.0 & \\
\hline $60+$ & 16 & 6.6 & \\
\hline \multicolumn{4}{|c|}{ Household Size } \\
\hline$<5$ & 39 & 16.3 & \multirow{5}{*}{$7.8(\mathrm{SD}=3.7)$} \\
\hline $5-10$ & 136 & 56.7 & \\
\hline $11-15$ & 47 & 19.6 & \\
\hline $16-20$ & 16 & 6.6 & \\
\hline $21+$ & 2 & 0.8 & \\
\hline \multicolumn{4}{|c|}{ Marital Status } \\
\hline Single & 28 & 11.7 & \\
\hline Married & 176 & 73.3 & \\
\hline Divorced & 22 & 9.2 & \\
\hline Widowed & 14 & 5.8 & \\
\hline \multicolumn{4}{|c|}{ Years of Formal Schooling } \\
\hline 0 & 42 & 17.5 & \multirow{5}{*}{$8.5(\mathrm{SD}=5.7)$} \\
\hline $1-6$ & 17 & 7.1 & \\
\hline $7-12$ & 82 & 34.2 & \\
\hline $13-18$ & 84 & 35.0 & \\
\hline $18+$ & 15 & 6.2 & \\
\hline \multicolumn{4}{|c|}{ Experience } \\
\hline$<5$ & 14 & 5.8 & \multirow[t]{4}{*}{$16.0(\mathrm{SD}=9.3)$} \\
\hline $5-15$ & 95 & 39.6 & \\
\hline $16-25$ & 74 & 30.8 & \\
\hline $26+$ & 57 & 23.8 & \\
\hline \multicolumn{4}{|c|}{ Extension Contact Per Year } \\
\hline$<5$ & 150 & 62.5 & \multirow{3}{*}{$7.7(\mathrm{SD}=8.34)$} \\
\hline $5-10$ & 75 & 31.3 & \\
\hline $11+$ & 15 & 6.2 & \\
\hline
\end{tabular}

Source: Field Survey, 2012.

3.2 Categories of Adopters of Improved Oil Palm Fruit Processing Technology.

Table 2 relays the categories of adopters of improved oil palm fruit technology in the study area.

Table 2: Distribution of Respondents According to Categories of Adoption of the Technology.

\begin{tabular}{lccc}
\hline Adoption category & Frequency & Percentage (\%) & Cumulative (\%) \\
\hline Non-adoption & 153 & 63.8 & 63.75 \\
Discontinuance & 6 & 2.5 & 67.25 \\
Using and planning & & & 70.58 \\
to stop & 8 & 3.3 & 100.0 \\
Continuous adoption & 73 & 30.4 & - \\
Total & $\mathbf{2 4 0}$ & $\mathbf{1 0 0 . 0}$ & \\
\hline
\end{tabular}

Source: Field Survey, 2012. 
Table 2 shows that $2.5 \%$ of the oil palm fruit processors in the study area representing about $7 \%$ of the adopters have discontinued with adoption. Similarly, about $3 \%$ of the respondents representing about $9 \%$ of the adopters are planning on discontinuing with the innovation. The discontinuance and plan to discontinue use of the innovation could be as a result of high cost of the technology, fuel (diesel), and maintenance as well as unavailability of credit facilities.

Table 2 also shows that $30.4 \%$ of the oil palm fruit processors in the study area representing about $82.9 \%$ of the bulk of the adopters expressed their decision to continue using the machine probably due to the fact that more oil is realized with machine technology. Nwajiuba and Akinsanmi (2003) underscored this fact when they pointed out that with machine technology output of oil extraction is about $50 \%$ more and that $25 \mathrm{~kg}$ of palm fruits which used to yield about 30 litres of fresh palm oil now yields up to 45 litres of fresh palm oil.

\subsection{Reasons for Non-adoption of Improved Oil Palm Fruit Processing Technology}

Reasons for non-adoption of the technology as captured in the study area are presented in Table 3. Table 3: Respondents Distribution According to Reasons for Non-adoption of the Technology.

\begin{tabular}{lccc}
\hline Non-adoption Reasons & Frequency $(\mathbf{n}=\mathbf{1 5 3}) *$ & Percentage (\%) & Rank \\
\hline High cost of machine & 105 & 68.6 & 1 \\
Low level of extension visits & 103 & 67.3 & 2 \\
Poor quality of oil produced & & & 3 \\
using the machine & 97 & 63.4 & 4 \\
Lack of operational skills & 76 & 49.7 & 5 \\
Inefficiency of machine & 10 & 6.5 & \\
\hline
\end{tabular}

Source: Field Survey, $2012 *$ Multiple responses

Data in Table 3 show that while high cost of the machine was the respondents' major reason for not adopting the innovation, low level of extension visits was another reason adduced for non-adoption of the technology. Oladele (2005) reported that the propensity to adopt improved beans and maize varieties in Southern Nigeria was influenced by extension visit. Supporting this finding, Anyaegbunam, Eze, Ogbonna, and Korieocha (2009) found that major problems hindering adoption of improved technologies were high cost of input, unavailability of credit, inadequate access to land and insufficient extension services.

Another reason for non-adoption of the technology is the quality of oil produced using the machine which makes it to be largely seen as inferior to the manually produced oil. This finding is in consonance with that of Lade (2007) in Ofoka (2014) that in addition to other problems associated with machine processed oil, there is overall low quality with high iron content (residues from oil machines) which might endanger the health of the poorest who consume the lowest quality oils available. Again, this further underscores the kitchen preference of the manually processed oil. Lack of operational skills is another reason. The high level of technical input required to use a technology might be a factor militating against the adoption of innovations.

\subsection{Reasons for Discontinuance of Improved Oil Palm Fruit Processing Technology}

Reasons for discontinuance of improved oil palm fruit processing technology in the study area are relayed in Table 4.

Table 4: Respondents Distribution According to Reasons for Discontinuance of Improved Oil Palm Fruit Processing Technology.

\begin{tabular}{lccc}
\hline Reasons for Discontinuance of the Innovation & Frequency $(\mathbf{n}=\mathbf{1 4}) *$ & Percentage (\%) & Rank \\
\hline High cost of machine & 14 & 100.0 & 1 \\
Low level of extension visits & 13 & 92.8 & 2 \\
Poor quality of oil produced & 11 & 78.6 & 3 \\
using the machine & 10 & 71.4 & 4 \\
Lack of operational skills & 55 & 35.7 & 5 \\
Inefficiency of machine & & &
\end{tabular}

Source: Field Survey, $2012 *$ Multiple responses

Table 4 relays that the most prominent reasons for discontinuance or plans to discontinue use of the innovation are high cost of machine (100.0\%) and low level of extension visits (92.8\%). Oladele and Kareem (2003) have shown that high cost of technology is a reason for non-adoption and discontinuance of innovation. Low level of extension visit was also fingered. Okoye (1998) argued that lack of adequate extension visits is a factor responsible for discontinuance. In line with these submissions, Adebayo, Anyanwu and Dsiyale (2003) pointed out that most persons will adopt a new idea if they have the resources and are not hampered by physical, social and organizational constraints. To buttress the above findings, Nnadi and Akwiwu in Imarhiagbe (2014), asserted that small sizes, cost, poor access to credit and inadequate extension information back up are the reasons for discontinuance of yam minisett technology in Imo State, Nigeria. 


\subsection{Conclusion and Recommendations}

Oil palm fruit processors in the study area were moderately educated as suggested by the average year of schooling of 8.5 years. Education has been found to increase individuals' adaptive capacity to decide on adoption of innovations like improved oil palm fruit processing technology. Based on this factor, oil palm processors were desirous and ready to adopt the improved technology. However, more than half of the processors could not adopt the technology because of high cost of purchase of machine, fuel (diesel) and maintenance. All these among others resulted in gradual discontinuance of the use of the technology.

Based on the findings from the study, it is suggested that the improved processing technology should by subsidized by both government and international donor organizations for processors to procure and own at affordable prices. This will encourage adoption and sustenance of the technology. To solve the problem of high cost of fuel (diesel) pointed out as one of the major reasons for discontinuance or plans to discontinue use of the innovation, solar technology should be mass produced and supplied to prospective processors as this would remove or eliminate fueling issue. This is in addition to extension of credit facilities to oil palm processors in the study area by government and financial houses without stringent and frustrating conditionalities.

\section{References}

Adah, O.C., Chia, J.I. \& Shaibu, M.U. (2016), Assessment of rural farmers' attitudes toward agricultural insurance scheme as a risk management strategy in Kogi State, North central Nigeria. Journal of Economics and Sustainable Development. 7(14) 12-19.

Adah, O.C., \& Obinne, C.P.O. (2015), Analysis of extent of awareness and adoption of improved oil palm fruit processing technology in Kogi State, Nigeria. Journal of Biology, Agriculture and Healthcare. 5(20) 5-10.

Adebayo, K., Anyanwu, A.C. \& Dsiyale, A.O. (2003), Perception of environmental issues by cassava processors in Ogun State, Nigeria: Implications for environmental extension education. Journal of Extension System. 19 103-112.

Agbamu, J.U. (2006), Essentials of agricultural communication in Nigeria. Lagos, Malthouse Press Limited. $47-$ 81.

Agwu, A.E. (2006), Adoption of improved oil palm production and processing technologies in Arochukwu Local Government Area of Abia State, Nigeria. Agroscience: Journal of Agriculture, Food, Environment and Extension. 5(1) 25-35.

Akubuilo, C.J.C. (2008), Modern approaches to agricultural extension. Enugu, New Generation Books. 31-56.

Anyaegbunam, H.N.; Eze, C.I., Ogbonna, M.C. \& Korieocha, D.S. (2009), Evaluation of factors driving the adoption of yam minisett technology by farmers in Abia State, Nigeria. The Nigerian Agricultural Journal. 40(1) $169-174$.

Hornik, R.C. (1999) Development communications: Information, agriculture and nutrition in the third world. Accessed on the $7^{\text {th }}$ May, 2014 from www.fao.org.

Idrisa, Y.I.; Ogunbameru, B.O. \& Madukwe, M.C. (2012), Logit and tobit analysis of the determinants of likelihood of adoption and extent of adoption of improved soybean seed in Borno state, Nigeria. Greener Journal of Agricultural Sciences. 2 37-45.

Imarhiagbe, P. (2014), Analysis of use and discontinuance of rubber technologies among small-scale farmers in Edo and Delta States, Nigeria. Unpublished PhD Thesis. Department of Agricultural Economics \& Extension, Kogi State University, Anyigba, Nigeria.

Khan, M.E., Anker, M., Patel, B.C., Barge, S., Sadhwani, H. \& Kolile, R. (1991), The use of focus groups in social and behavioural sciences. World Health Statistics Quarterly. $44145-148$.

Motuma, T., Dejene, A., Wondwossn, T., Roberto la Rovere, Girma, T., Mwangi, W., \& Germano, M. (2010), Adoption and continued use of improved maize seeds: A case study of central Ethiopia. African Journal of Agricultural Research. 5(17) 2350-2358.

Nsoanya, L.N. and Nenna, M.G. (2011), Adoption of improved cassava production technologies in Anambra-East Local Government Area of Anambra State, Nigeria. JORIND 9(2) 36-43.

Nwajiuba, C. and Akinsanmi, O.A. (2003), Implication of improved oil palm (Elaeis guineensis) fruit processing technologies for labour and income among rural households in Imo State, Nigeria. http://www. Tropentragide/2003/abstracts/full/138. pdf.

Ofoka, C.I. (2014), Technological capabilities of mechanical oil palm processors in Anambra State, Nigeria. Unpublished Ph.D Research Findings. Department of Agricultural Extension, University of Nigeria, Nsukka. 39-64.

Okoye, A.A. (1998), Factors affecting adoption process by farmers in selected Local Government Areas of Anambra State. Nigeria Journal of Agriculture. 24(1) 10-14.

Oladele, O.J. (2005), A tobit analysis of the propensity to discontinue adoption of agricultural technology among farmers in Southwestern Nigeria. Journal of Central European Agriculture. 6(3) 249-254.

Oladele, O.J. and Kareem, A.I. (2003), Adoption rate and continued use of selected arable crop technologies among 
farmers in Oyo State, Nigeria. Journal Central European Agriculture. 1(3\&4) 291-294.

Olagunju, F.I.(2008), Economics of palm oil processing in Southwestern Nigeria. International Journal of Agricultural Economics and Rural Development (IJAERD). 1(2) 69-77.

Oluyomi, M. S.; Audu, L. B.; \& Adah, O. C. (2016), Discontinuance of yam minisett technology utilization by farmers in Benue State, Nigeria. Journal of Agricultural and Crop Research. 4(6) 83-90.

Omereji, G.O.(2005), The oil palm industry in Nigeria: Cultivation, processing and trade. Benin-City, Mindex Publishers.

Onoh, P.A. and Peter-Onoh, C.A. (2012), Adoption of improved oil palm production technology among farmers in Aboh Mbaise Local Government Area of Imo State, Nigeria. International Journal of Agriculture and Rural Development. 15(2) 966-971.

Owolarafe, O.K., Taiwo, E.A. and Oke, O.O. (2008), Effect of processing conditions on yield and quality of hydraulically pressed palm oil. International Agrophysics. www.international.agrophysics.org 22 349-352.

Rogers, E.M. and Shoemaker, F.F. (1971), Communication of innovations: A cross-cultural approach. Second Edition. New York, The Free Press, Collier Macmillan Publishing Co. Inc. 